\title{
NARCISTIČNA RANJIVOST I RAZVOD BRAKA
}

\section{SAŽETAK}

Osobine ličnosti određuju karakterističan i dosljedan način ponašanja pojedinca, kao i načina reagiranja u stresnim situacijama. Opće je poznato kako je razvod braka jedan od najstresnijih događaja u životu pojedinca. Sposobnost prilagodbe pojedinca ovisi između ostalog i o prisutnosti narcisitičnih osobina ličnosti. Narcistična ranjivost je svojevrstan obrambeni mehanizam koji se aktivira u situacijama intenzivnog stresa izazvanog razvodom braka. To nije sinonim za kliničku dijagnozu narcističnog poremećaja, međutim, ovisno o razini povrede samopoštovanja pojedinca i poteškoćama oporavka, može prerasti u patološki narcizam. Narcistična ranjivost označava način na koji će pojedinac reagirati na udarce vezane uz vlastito samopoštovanje te u kojoj će mjeri udarci biti prijeteći za pojedinca. Većina ljudi će povrede s vremenom razriješiti i oporaviti se. Za razliku od većine, narcistično ranjiviji pojedinci, nakon doživljenih povreda teško će se oporaviti i očuvati vlastito samopoštovanje. Povrede mogu trajati dugi period, istim intenzitetom, a osoba može razviti narcistični poremećaj ličnosti. Visokokonfliktni razvod bra-

1 Dr. sc. Maja Ernečić, psihologinja, e-mail: maja.ernecic@kc.htnet.hr

2 Sonja Patričević, Sveučilišna specijalistica obiteljske medijacije, socijalna radnica, e-mail: sonja.patricevic@hotmail.com
Stručni članak

Primljeno: siječanj, 2015.

Prihvaćeno: studeni 2016.

UDK 159.964.2:347.624

DOI 10.3935/ljsr.v24i1.53

Maja Ernečić ${ }^{1}$

Sonja Patričević ${ }^{2}$

Centar za socijalnu skrb Koprivnica

Ključne riječi:

narcistična ranjivost, razvod braka, reakcija na stres, povreda samopoštovanja, narcistični poremećaj ličnosti. 
ka sve je više u fokusu interesa stručnjaka kao i šire javnosti. Velik dio studija bavi se psihološkim učincima konflikta na djecu, manipulativnim ponašanjima roditelja, kao i poteškoćama odgoja djece nakon razvoda. Ličnost roditelja u ovim se područjima prepoznaje kao bitna, međutim nedovoljno se objašnjava njen utjecaj. Ovaj rad jedan je od prvih koji se bavi razmatranjem psiholoških procesa narcističnog pojedinca u situaciji razvoda braka što može doprinijeti razumijevanju postupaka bivših partnera i boljem razumijevanju visokokonfliktnih razvoda braka koji su danas prepoznati kao izuzetno važan psihosocijalni problem.

\section{UVOD}

lako se narcizam prepoznaje kao ozbiljan mentalni poremećaj, njegove manifestacije ne moraju biti odmah prepoznate kao patološke, čak ni od strane stručnjaka pomažućih profesija. Freudov pionirski pogled (1914., prema Cohen, 1998.) prema kojem narcizam postaje patološka pojava kada pojedinac ne dovrši tranziciju koja podrazumijeva prelazak sa samoljublja na ljubav prema drugima je, s manjim izmjenama, ipak prihvaćena i danas. Konstrukt narcizma posjeduje dualnu prirodu u obliku zdravog/funkcionalnog i nezdravog/patološkog narcizma, pri čemu je ovaj drugi najpoznatiji kao narcistični poremećaj ličnosti (Čuržik i Jakšić, 2013.). Prvi je baziran na zdravom, a drugi na niskom samopoštovanju. Čuržik i Jakšić (2013.) smatraju kako je funkcionalni narcizam prisutan kod ljudi koji imaju ponešto preuveličanu sliku o sebi i sklonost kompetitivnom ponašanju, ali su opušteni u interpersonalnim odnosima, energični, a svoje osobine koriste kako bi bili uspješni. Patološki narcizam, prema istim autorima, uključuje neuspješne strategije nošenja s kritikama i sumnjama u vrline i kompetencije narcistične osobe, a u području kliničke psihologije i psihijatrije to je definirano kroz narcistični poremećaj ličnosti. Narcistični poremećaj ličnosti često je bio predmet opsežnih teoretskih rasprava, no vrlo rijetko predmet znanstvenih istraživanja (Morey i Stagner, 2012.). $\mathrm{U}$ ovom radu bavimo se narcističnom ranjivosti koja se aktivira kao mehanizam u situacijama intenzivnog stresa izazvanog razvodom braka.

\section{DEFINIRANJE POJMA NARCIZAM I NARCISTIČNA RANJIVOST}

Jedno od pitanja je gdje zdravi narcizam završava i gdje narcistični poremećaj počinje. DSM-IV (Američka psihijatrijska udruga, 1994.) postavlja granicu na mjestu gdje narcistične kvalitete počinju ometati pojedinca u osobnim odnosima. DSM-V 
(Američka psihijatrijska udruga, 2014.) u prvobitnoj verziji uopće nije prikazivao narcistični poremećaj ličnosti kao zasebnu dijagnostičku kategoriju, već u okviru antisocijalnog/psihopatskog tipa. O izostavljanju narcističnog poremećaja osobnosti iz DSM-V razvila se rasprava među stručnjacima koji se dublje bave ovim područjem, među kojima mnogi zastupaju stav kako to nije najbolje rješenje. Među njima je i Ronningstam (2011.) koja navodi da postoje snažni dokazi koji govore u prilog važnosti zadržavanja narcističnog poremećaja osobnosti kao zasebnog poremećaja ličnosti. Ronningstam (2011.) smatra da pojedinci s narcističnim poremećajem ličnosti pate od promjenjivog i ranjivog samopoštovanja što je njihova osnovna karakteristika, a koja bi trebala biti temelj dijagnostike. Promjenjivost karakteriziraju stanja koja se kreću od pretjeranog samopouzdanja, superiornosti i asertivnosti do inferiornosti i nesigurnosti. Ranjivost se očituje kroz pretjeranu reaktivnost, odnosno snažnu reakciju na percipirane izazove i prijetnje vlastitom samopoštovanju (poniženje, kritike...), uz prikrivene ili otvorene snažne osjećaje ljutnje, neprijateljstva, zavisti, izrazite samokritičnosti ili srama, te promjene raspoloženja, kao i izbjegavajuća, osvetnička ili obmanjujuća ponašanja. Kasnije, u revidiranoj verziji DSM-V narcistični je poremećaj ipak uvršten u klasifikaciju psihičkih poremećaja (Miller i sur., 2013.).

Cohen (1998.) kao najvažniju narcističnu kvalitetu ističe grandiozni osjećaj vlastite vrijednosti kojim narcistični pojedinac kompenzira manjkavo poimanje sebe i izrazitu ranjivost. Različite manifestacije narcizma, počevši od grandioznosti te svih ponašanja i stavova koji ju podupiru, zamišljene su kao sredstvo za održavanje krhkog samopoštovanja (Raskin, Novacek i Hogan, 1991.). Tako narcistični pojedinac preuveličava svoju važnost, postignuća, sposobnosti, talente i nastojanja, a istovremeno se odcjepljuje, disocira ili potiskuje negativne elemente "selfa« i projicira ih na druge. Grandioznost kao ključan element narcizma prepoznaje i Cramer (2011.) koji o narcizmu govori kao o prisutnosti vrlo visokog i "prenapuhanog« osjećaja vlastite vrijednosti, ovisnosti o tuđem divljenju, maštanjem o slavi i moći, pojačanoj osjetljivosti na kritike, uz nedostatak predanosti i brižnosti u međuljudskim odnosima. Da je u srži narcizma pitanje promjenjivosti i ranjivosti samopoštovanja, zaključili su i Baris i sur. (2001.) te narcističnost jednostavno definirali »kao normaIan ili nenormalan način reguliranja samopoštovanja«. Njihova definicija u kojoj je ključna riječ reguliranje, narcizam posve pojednostavnjuje. Drugim riječima, za ove autore narcizam je svaka mentalna aktivnost posvećena očuvanju strukture i stabilnosti vlastitog ega. Narcizam vide kao sklop psiholoških funkcija koje se aktiviraju kada je samopoštovanje pojedinca narušeno. Narcistična ponašanja pri tom imaju samo jednu svrhu, a to je da osjećaj nanesene štete dovedu na razinu s kojom se pojedinac može nositi. U suštini, to je psihološki proces oporavka samopoštovanja. Ovisno o dubini i intenzitetu povrede samopoštovanja, narcistična 
ponašanja su blaga ili intenzivna, a ishod konačne prilagodbe u povratku ravnoteže može se smatrati normalnim ili nenormalnim. Narcistično »uravnotežavanje« samopoštovanja postaje patološko kada osoba mora iskriviti vlastitu realnost kako bi vratila osjećaj ravnoteže. Primjerice, što je pojedincu teže prihvatiti činjenicu da je učinio nešto loše, veća je vjerojatnost da se neće osjećati krivim, već će projicirati krivnju na drugu osobu ili događaj. Kada je priznavanje pogreške toliko ugrožavajuće za sliku o sebi i samopoštovanje, osoba mora okriviti nekog drugog. Samopoštovanje je, u suštini, osjećaj vlastite vrijednosti, odnosno osjećaj vrijednosti sebe kao ljudskog bića. Narcizam sam po sebi nije samopoštovanje ili samoljublje, već ponašanje koje osoba manifestira kako bi kod sebe same zadržala visoku razinu samopoštovanja. Drugim riječima, to je proces ljudskog funkcioniranja koji omogućava pojedincu da nadgleda i prilagođava vlastitu percepciju samog sebe kao vrijednog. Normalno je da samopoštovanje fluktuira s obzirom na pozitivna i negativna iskustva koja osoba ima s drugim ljudima, kao i s obzirom na procjenu vlastitih uspjeha, prema svojim vlastitim kriterijima. Što je procjena vlastitih postignuća sličnija viđenju samog sebe, veći je i osjećaj zadovoljstva, kompetentnosti i vrijednosti, a samim time smanjuje se prijetnja vlastitom samopoštovanju. Vrlo slično dosadašnjim pogledima, na narcizam gledaju i Stoorow i Lachman (1980., prema Baris i sur., 2001.) koji smatraju da narcizam utjelovljuje one mentalne procese kojima je zadatak reguliranje samopoštovanja, održavanje kohezije i stabilnosti vlastite prezentacije. Autori smatraju da se narcistična ponašanja aktiviraju kako bi zaštitila, sačuvala, oporavila i stabilizirala samopoštovanje, u situacijama kada je ono ugroženo, značajno sniženo ili uništeno.

Posljednjih godina stručna se javnost sve više bavi i drugim aspektima narcističnog poremećaja ličnosti, odnosno njegovim različitim podtipovima. Levy (2012.) zaključuje kako postoje temeljno dvije različite slike narcistične disfunkcionalnosti - grandiozni i vulnerabilni narcizam - koje se razlikuju prema strategijama nošenja s vlastitim emocijama, samopoštovanjem i interpersonalnim odnosima. Grandiozni tip karakteriziraju preuveličana slika o sebi, dojam o vlastitoj posebnosti i pravima, dominacija, iskorištavanje i okrivljavanje drugih, intenzivna zavist, nedostatak empatije, česti napadaji bijesa i agresije, i što je najvažnije, nesposobnost da se svjesno osjeća sram. Nasuprot tome, vulnerabilna narcistična ličnost također ima idealizirane fantazije o sebi, ali istovremeno osjeća intenzivan sram i krivnju vezano uz vlastite potrebe i ideje. Tu nije dominantna zavist i posljedična agresivnost, već samokritičnost, depresivnost, potencijalna suicidalnost te pretjerana osjetljivost na kritiku od drugih povezana sa socijalnim povlačenjem, odnosno izbjegavanjem međuljudskih odnosa (Miller i sur., 2013.). Da narcistični poremećaj ličnosti nije homogen entitet, smatraju i Čuržik i Jakšić (2013.) koji navode da postoje određene teorijske i empirijske indikacije prema kojima postoje određeni

\section{0 članci}


podtipovi narcističnog poremećaja ličnosti, što je u skladu s razmatranjima Levy (2012.).

Narcistična ranjivost središnje je područje interesa ovog rada. Ona je povezana s ranijim životnim iskustvima osobe, njenim izrečenim i nesvjesnim stavovima o braku i intimnosti, i njenom sposobnošću da prihvati odgovornosti, kao i da podnosi emocionalnu bol. Međutim, važno je odmah na početku napomenuti da narcistična ranjivost nije sinonim za kliničku dijagnozu narcističnog poremećaja. O patološkom narcizmu poznatijem kao narcistični poremećaj ličnosti dovoljno je bilo govora u samom početku rada. Ovdje pod pojmom narcistična ranjivost zapravo podrazumijevamo način na koji će pojedinac reagirati na udarce vezane uz vlastito samopoštovanje te u kojoj će mjeri udarci biti prijeteći za pojedinca. Većina ljudi u životu doživjet će određene povrede koje mogu biti prijeteće za njihovo samopoštovanje. Isto tako, većina će ih razriješiti i oporaviti se, bez trajnih posljedica na njihovo funkcioniranje. Drugi, narcistično ranjiviji pojedinci, nakon doživljenih povreda teško postižu oporavak vlastitog samopoštovanja. Za njih udarci na samopoštovanje mogu biti toliko teški da se od njih ne mogu oporaviti, povreda će se sjećati godinama nakon što su se dogodile i proživljavat će in jednakim intenzitetom. Kod takvih pojedinaca doživljena povreda može izazvati prelazak iz zdravog u patološki narcizam ili razvoj poremećaja osobnosti. Ovdje, u ovom radu govorit ćemo upravo o tim pojedincima.

\section{NARCISTIČNA LIČNOST I RAZVOD}

Ličnost je ta koja određuje kako će pojedinac reagirati na razvod. Osobine ličnosti pridonose bračnoj stabilnosti, ili razvodu braka, zbog toga što pomažu u oblikovanju kvalitete dugoročnih odnosa. Roberts i sur. (2007.) navode da je neuroticizam, kao osobina ličnosti, jedan od najjačih i najdosljednijih prediktora nezadovoljstva u odnosu, sukoba, zlostavljanja, i na kraju, raskida odnosa. Isti autori smatraju da postoje tri različita načina na koje osobnost pojedinaca utječe na ishode njihovih odnosa s drugim ljudima. Prvo, osobine ličnosti utječu općenito na uspostavljanje odnosa s drugim ljudima. Drugo, osobine ličnosti oblikuju reakcije ljudi na ponašanje drugih ljudi, između ostalog i bračnih partnera. I treće, osobine ličnosti pojedinaca kod partnera izazivaju ponašanja koja pridonose, ili narušavaju, kvalitetu odnosa.

Osobine ličnosti i njihovu povezanost s razvodom braka najčešće razmatramo u kontekstu visokokonfliktnog razvoda braka. Psihološki učinci visokokonfliktnih razvoda na djecu dobro su poznati. Mnogo manje se zna o psihološkim karakteristikama odraslih odgovornih za sukob, a još manje o tome kako psihološke poteškoće roditelja predviđaju i utječu na trajanje konflikta nakon razvoda (Donner, 
2006.). Relativno mali broj istraživanja bavio se karakteristikama osobnosti razvedenih pojedinaca koje rezultiraju sukobom (Malcore i sur., 2010.), a znanstvena literatura koja se bavi tim specifičnim područjem relativno je oskudna. Najveći dio radova objavljenih na tu temu datira iz vremena 90 -ih godina prošlog stoljeća. Tako se i Donner (2006.) koji je objavio jedan vrlo vrijedan rad na temu utjecaja ličnosti pojedinaca na trajne sukobe u procesu brakorazvoda poziva mahom na izvore iz 90-ih, a dijelom i na izvore koji datiraju i iz ranijih godina prošlog stoljeća.

Ispitivanje čimbenika koji stvaraju i održavaju visokokonfliktnim roditeljski odnos nakon razvoda već je više desetljeća predmet istraživanja mnogih znanstvenika. Johston i Campbell (1988.) su još prije dvadesetak godina postavili tezu prema kojoj sukobi potencirani razdvajanjem - poniženje vezano uz odbijanje, tuga vezana uz gubitak, općenita bespomoćnost kao odgovor na prijeteće životne promjene $-u$ interakciji s ranjivom osobnosti kod nekih pojedinaca te pojedince čine posebno sklonima stalnom neprijateljstvu i nerješivim konfliktima. Autori su proveli istraživanje na uzorku od 8 obitelji i došli do zaključka da $2 / 3$ roditelja ima dijagnozu poremećaja osobnosti. lako dobivene rezultate treba uzimati s oprezom s obzirom na veličinu uzorka, autori su srž problema pripisali narcističnoj ranjivosti pojedinaca. Njihova je postavka da razvod sa svim svojim implikacijama neuspjeha, gubitka, odbacivanja i bezvrijednosti predstavlja ogroman udarac na ego tih pojedinaca. lako veličina uzorka nalaže oprez u zaključivanju, rezultati istraživanja značajni su jer ukazuju da postoji trend u kojem pojedinci u razvodu, posebno visokokonfliktnom, često pate od poremećaja osobnosti. Kasnije je Johnston (1994.) proširio taj model smatrajući da na sukobe osim čimbenika na individualnoj razini utječu i čimbenici na izvanjskoj socijalnoj razini i interakcijskoj razini.

Obrambeni stav je jedna od najčešćih karakteristika osobnosti koja se pojavljuje u istraživanjima visokokonfliktnih razvoda. Visokokonfliktni pojedinci imaju obrambeni stav i poriču vlastitu odgovornost za bilo koji problem, projicirajući velik dio krivnje na partnera. Sebe vide kao osobe koje su živjele s pogrešnom osobom i tu »pogrešnu osobu« krive za postojeći konflikt. Nemaju uvid u stvarne razloge konflikta i vlastitu odgovornost. Osobe uključene u visoki konflikt mnogo su češće reaktivne nego pasivne. Reaktivni pojedinci imaju problema s inhibicijom i češće reagiraju na snažan emocionalni podražaj. Mnogo češće će reagirati eksplozivno nego što će se osjećati anksiozno ili krivo. Stručnjaci ih često opisuju kao histrionske ili narcistične osobnosti.

Kod narcističnih osobnosti važnost osjećaja grandioznosti te ponašanja i mehanizama koji je podržavaju može se najbolje vidjeti kada takva osoba "pukne«. Ona na kritike i na neizbježne neuspjehe i stresove života reagira intenzivnim osjećajima bijesa, srama ili poniženja (Kernberg, 1984., prema Cohen, 1998.). Kohutov (1972., prema Bilić i sur., 2013.) način gledanja na narcistične osobnosti vrlo je sli-

\section{2 članci}


čan. Međutim, Kohut još dodatno spominje osjećaje praznine i depresije koje se javljaju kod narcističnih osoba kada se susretnu bilo s kritikama ili poteškoćama. Kohut (1972., prema Bilić i sur., 2013.) takve osjećaje vidi kao pokazatelj sniženog osjećaja vlastite vrijednosti pojedinca, gdje se grandioznost i potreba za stalnim dokazivanjem pojavljuju kao obrambeni mehanizam. Situacija razvoda sasvim sigurno je jedna od onih koja djeluje ugrožavajuće za njihovo samopouzdanje.

Pojedinci s narcističnim osobinama ličnosti skloni su konfliktnim odnosima, odnosno vezama, sobzirom da su ovisni o divljenju i pažnji koju dobivaju od svojih partnera (Gaulier i sur., 2007.). Izloženi stresu od gubitka braka, osjećaju se posebno deprivirani i željni divljenja zbog čega se okreću prema djeci i drugima da bi zadovoljili te potrebe. Autori također navode neke od specifičnih karakteristika ličnosti koje dovode do visokokonfliktnog razvoda i do produžavanja konflikta. Pri tome spominju rigidnost, potrebu za kontrolom, obrambeni stav i reaktivnost. Rigidna osoba pokazuje tendenciju sagledavanja bivšeg partnera kao loše osobe i isključivog krivca za razvod. Takva, rigidna osoba nedostupna je za rad na problemima jer nije u stanju pregovarati i postići kompromis. $U$ roditeljskoj sferi to bi bio roditelj s kojim se nije moguće dogovoriti gotovo niti oko čega što zahtijeva fleksibilnost. Potreba za kontrolom je usko povezana s rigidnošću. Jedna od najčešćih pritužbi koja se može čuti od partnera vrlo kontrolirajuće osobe je: »Još uvijek pokušava upravljati mojim životom kao da smo još uvijek u braku«. Pokušaj takve osobe da uspostavi kontrolu nad bivšim partnerom nailazi na otpor što može dodatno intenzivirati potrebu da se kontrolira situacija u kojoj jedna osoba želi neovisnost, a druga želi kontrolu. Načelno, može se reći da će pojedinci koji su rigidni, nefleksibilni, zaokupljeni crno-bijelim načinom razmišljanja, kontrolirajući i posesivni te vrlo reaktivni, vjerojatno upasti u visoki konflikt nakon razvoda braka. Isto tako, ako su vrlo usmjereni na sebe, a nakon razvoda ne uspijevaju zadovoljiti svoje potrebe, počinju koristiti konflikt i djecu kako bi zadovoljili svoje potrebe.

No, odakle proizlaze osjećaji ranjivosti koji dovode do tako intenzivnih reakcija? Baris i sur. (2001.) daju jedan od mogućih odgovora govoreći o narcističnim ranama. Autori tvrde da je jedan od uzroka ranjivosti reaktivna trauma vezana uz raniji gubitak (npr. smrt roditelja ili raniji gubitak djeteta...), a drugi proizlazi iz dugoročnih teškoća vezanih uz sam raskid i proces razdvajanja vlastitog identiteta od identiteta koji proizlazi iz veze s partnerom, što može rezultirati ovisnim, potpuno neovisnim ili izrazito ambivalentnim stavom prema bivšem partneru. Autori polaze od činjenice da je razvod vrlo ponižavajuće iskustvo, čak i za psihološki zdravu osobu. Pojedinci s krhkim samopoštovanjem posebno su ranjivi i skloni »raspadanju« u situaciji kada se javlja osjećaj srama zbog neuspjeha braka. Kada je samopoštovanje ugroženo, javljaju se distorzije realnosti. Distorzije su vrlo česte i uobičajena su pojava u samom početku razvoda i stresu koji nosi sa sobom. Međutim, kada se 
zadržavaju dugo vremena i ne korigiraju se, niti nestaju, pa čak i nakon što osoba primi nove i objektivne informacije na temelju kojih bi trebala promijeniti svoje mišljenje, one postaju problem i znak psihičke bolesti.

Razvod sa sobom uvijek nosi poruku neuspjeha koja tada sa sobom povlači i pitanje udjela odgovornosti svakog partnera za propast braka. Narcistično povrijeđeni pojedinci su vrlo osjetljivi i znaju vrlo pretjerano reagirati na to pitanje. Njihovo je samopoštovanje nerealno visoko ili nisko. Mogu se osjećati potpuno bezvrijedni ili prenapuhane vlastite vrijednosti. Racionalizacije se pojavljuju u obliku konstatacija: »Uvijek sam se osjećao krivim, ali sad znam da je ona bila manjkava osoba, a ja samo nevina žrtva njezinih podvala«.

U kontekstu održavanja samopoštovanja Barris i sur. (2001.) govore o obrambenim stilovima kod visokokonfliktnih ličnosti. Kako bi postigli ravnotežu u samopoštovanju, pojedinci koriste mnoge psihološke obrane. Jedna od njih koja je gotovo uvijek prisutna je projekcija krivnje. Važno je znati kako projekcija krivnje može biti prikazana kada se radi s osobom u visokokonflitnoj razvodnoj situaciji.

Tri su obrambena stila na koja se često nailazi:

1. Ja sam uvijek u pravu - ti su pojedinci apsolutno spokojni u vjerovanju kako su uvijek u pravu. Oni su vrlo samousmjereni i misle o sebi kao o jedinima koji imaju pravo na istinu.

2. Moj bivši je uvijek u krivu - ako osoba koja je uvijek u pravu predstavlja utjelovljenje napuhanog samoljublja i samouvažavanja, tada »ti si uvijek u krivu« osoba prezentira sadržaj projicirane krivnje. To su vrlo često ljuti, previše kontrolirajući ljudi s kojima nije ugodno biti u društvu. Navode niz »teških zločina« i pogrešaka bivšeg partnera i obično o njima govore s velikim žarom i iskrenim uživanjem. Često o događajima govore na način da djeluju kao da su se dogodili unazad kratkog vremena, a zapravo se radilo o događajima od prije dvije-tri godine. Kada bivšeg partnera drži isključivim krivcem, pojedinac u potpunosti štiti samog sebe od ikakve krivnje, a time i od osjećaja srama da je učinio nešto loše. To su ljudi koji žive u prošlosti i za prošlost.

3. Možda hoću, možda neću - to su osobe čija ljutnja udara »od ispod « i »od iznad«. lako njihova ljutnja nije stalna, ona je vrlo blizu površini i isplivava i na najmanju provokaciju. Takve su osobe u pravilu vrlo nefokusirane. Vrlo je teško razumjeti strukturu njihove logike koja je pod velikim utjecajem ljutnje. S njima može biti najteže raditi jer rad može biti vrlo frustrirajući zbog njihovog konstantnog nepovezanog blebetanja, koje proizlazi iz njihove ljutnje (Garrity i Baris, 1994., prema Barris i sur., 2001.).

\section{4 članci}




\section{NARCISTIČNA RANJIVOST I RODITELJSTVO}

Ovisno o premorbidnoj strukturi ličnosti i obrambenim mehanizmima, specifičnim ranijim iskustvima iz djetinjstva te eventualnim nedavnim traumatskim iskustvima, roditelji u razvodu imaju različite kapacitete da se nose s emocijama vezanima uz sam razvod i da ih integriraju. Većina visokokonfliktnih roditelja su oni psihološki ranjiviji koji uz to imaju slabije sposobnosti da se nose s osjećajima ranjivosti (Johnston i Campbell, 1988.). Unutarnji psihološki konflikti nesvjesno potiču razmirice oko djece direktno umanjujući kapacitete roditelja za donošenje racionalnih odluka i suradnju. Narcizam i narcistična ranjivost smatraju se najčešćim psihološkim borbama pojedinaca u visokokonfliktnim razvodima.

Narcistična bi se ranjivost mogla opisati kao sklonost da se na povrede koje mogu biti i minimalne reagira značajnim gubitkom samopouzdanja (Bilić i sur., 2013.). Narcistično ranjive osobe odgovaraju na aktualnu ili anticipiranu narcističnu povredu sramom i povlačenjem (bijeg) ili narcističnim bijesom (borba). Narcisični se bijes otkriva u mnogo oblika. Potreba za osvetom, za ispravljanjem krivog, te duboko utemeljena, nesmanjena, prisila za slijeđenjem svog osvetoljubivog cilja neke su od najvažnijih karakteristika fenomena narcističnog bijesa. One ga odvajaju od drugih vrsta agresije. U tipičnim oblicima narcističnog bijesa dolazi do potpunog zanemarivanja razumskih ograničenja i postoji samo bezgranična želja za zadovoljštinom i osvetom zbog nanesene povrede. Iracionalnost tog osvetničkog stava još je više zastrašujuća, ističe Kohut (1972., prema Bilić i sur., 2013.), zbog činjenice da je u narcističnih osobnosti, kao i u paranoika, dok su potpuno pod dominacijom i utjecajem najsnažnijih emocija, sposobnost rasuđivanja često intaktna pa čak i zaoštrena.

Narcistični pojedinci opterećeni su time kako moraju biti jedinstveni po nečemu, najbolji. U svojem perfekcionizmu oni stvaraju visoke i nerealne, zapravo nedostižne ciljeve, zbog čega u konačnici umjesto osjećaja osobnog ostvarenja nastaje sram, poniženje i očaj. Zapravo, možemo reći da kod narcisa postoji tzv. procjep jastva (eng. self), odnosno razlika između idealnog doživljaja i realnog jastva. Razlika između idealnog jastva, onog što želimo biti, i stvarnog jastva, odnosno onog što stvarno jesmo, određuje jačinu srama i poniženja koji će osoba osjećati (Bilić i sur., 2013.).

Za većinu ljudi razvod uključuje prijetnju vlastitom samopoštovanju i narušavanju slike o sebi, kao supružnika i/ili kao roditelja. Međutim, dok neki pojedinci odbacivanje u razvodu doživljavaju kao udarac na samopoštovanje, drugi ga doživljavaju kao općenito ponižavajući napad na sebe. Stupanj do kojeg će se pojedinac osjećati ugroženo, ovisi o stupnju ugroženosti njegovog narcizma, koji je u funkciji očuvanja njegova vlastitog identiteta. 
Narcistično ranjivi pojedinci razlikuju se po intenzitetu poteškoća koje imaju u vlastitoj sposobnosti da sačuvaju pozitivnu sliku o sebi i jasan osjećaj vlastitog identiteta, koji lako mogu biti ugroženi ili povrijeđeni. Johnston i Campbell (1988.) narcističnu ranjivost razlikuju na kontinuumu od blage narcistične ranjivosti, preko umjerene, pa sve do teško narcistično ranjivih pojedinaca. $U$ ovom dijelu donosimo kratak pregled njihove klasifikacije.

\section{Blaga narcistična ranjivost}

Prema Johnston i Campbell (1988.), na najmanje ranjivom kraju kontinuuma su pojedinci koji imaju relativno stabilan osjećaj sebe, ali koji imaju posebnu ranjivost u održavanju pozitivnog samopoštovanja. Imaju poteškoća u održavanju osjećaja vlastite vrijednosti na temelju vlastitih (unutarnjih) izvora pa se okreću drugima koji podupiru njihove dobre osjećaje o njima samima. Većinu takvih pojedinaca možemo svrstati u jednu od dvije skupine. Prva skupina ima nisku razinu samopoštovanja i pojačan osjećaj neadekvatnosti, neuspjeha i odbacivanja. Zbog sniženog osjećaja samopoštovanja, kada u situacijama krize ne mogu zadržati pozitivnu ravnotežu, okreću se drugima kako bi zadobili njihovo odobravanje. Druga skupina ima preuveličanu sliku sebe i nerealna očekivanja o tome kako su se drugi »dužni« ponašati se prema njima. Njihovi napuhani standardi traže primjerenu potvrdu koju je teško dobiti, pogotovo tijekom krize. Posljedično, osjetljiviji su na osjećaj prijetnje vlastitom samopoštovanju. Djeluju kao osobe preplavljene mješavinom šoka, blagog gnjeva, razočaranja, frustracije i ljutnje prema bivšem supružniku. U roditeljskoj ulozi mnogi takvi pojedinci tvrdoglavo odbijaju surađivati s drugim roditeljem sve dok im bivši supružnik ne da priznanje i dok se ne počne "ponašati kako treba« - dok ne počne govoriti pristojno ili »pokaže neko razumijevanje«, sve dok se, u stvari, njihovo samopoštovanje ne oporavi. Ipak, suprotno od umjereno i teško narcistično ranjivih, blago narcistično ranjivi pojedinci, jednom kada dobiju priznanje, mogu promijeniti svoje stavove i postati fleksibilniji. Međutim, ako se bivši partner takvom blago narcistično povrijeđenom pojedincu otvoreno suprotstavlja, on će se nerijetko okrenuti javnoj areni sudova radi dobivanja priznanja svojih osjećaja, validacije ispravnosti svojih stajališta i dokaza da nije neuspješan kao supružnik ili roditelj. lako je ranjiv pojam o sebi blago narcistično ranjivih pojedinaca plodno tlo za sukob, često je interakcija s bivšim partnerom i uključenost drugih ono što izaziva i produljuje njihove sukobe. Njihovi roditeljski napori često postaju pretjerani, djecu prezaštićuju ili in pretjerano pritišću, u nastojanju da pokažu kako su dobri roditelji. Istovremeno, postaju ovisni o povratnim odgovorima svoje djece koji znače potvrdu njihovog roditeljstva. Znakove nezadovoljstva djece uzimaju kao odbacivanje i dokaz roditeljske nekompetencije. Posljedično, postaju

\section{6 članci}


emocionalno teški svojoj djeci u konstantnim zahtjevima za potvrdom da su dobri roditelji. Ipak, roditelji blage narcistične ranjivosti imaju kapaciteta uvidjeti svoju djecu realno, i kada ih se suoči s ponašanjem, u stanju su prepoznati posljedice svojih ponašanja na djecu i promijeniti ih.

\section{Umjerena narcistična ranjivost}

Umjereno narcistično ranjivi pojedinci su oni koji nemaju dobro uspostavljen osjećaj vlastite vrijednosti i imaju poteškoća zadržati pozitivnu, cjelovitu i realnu sliku sebe. Neosjetljivi su na želje i potrebe drugih, očekuju za sebe posebne usluge i privilegije, bez uzvratnog odnosa. Očekuju ispunjavanje vlastitih zahtjeva od strane bivšeg supružnika, u suprotnom postaju bijesni. Vidjeti sebe kao »lošeg« i/ili bivšeg partnera kao »dobrog«, za umjereno narcistično ranjive pojedince je iznimno konfuzno i izaziva anksioznost. Zbog toga konstruiraju negativnu sliku o bivšem partneru, kao obranu od pogleda na sebe u negativnom smislu. $U$ roditeljskoj ulozi funkcioniraju kao da imaju poremećaj ličnosti koji karakterizira značajna ranjivost na gubitak integrirane i pozitivne slike o sebi. Glavni obrambeni i kompenzacijski stil je nastojanje da se održi strogo pozitivna i izuzetno idealizirana slika o sebi. Većina takvih roditelja sebe vidi kao superiorne, misle da ne trebaju surađivati s drugim roditeljem, vjeruju da su najbolji i jedini roditelj. Takvi roditelji sud doživljavaju kao osvetničku arenu. Sud im treba da bi "pobijedili«, dobili potvrdu da su ispravni. Djecu teško vide odvojeno od samih sebe. Imaju ograničene sposobnosti prepoznavanja i odgovaranja na dječje potrebe, a svoje potrebe i želje pretpostavljaju dječjima. Probleme kod djece obično poriču ili ih vide kao grešku drugog roditelja. $U$ potrebi da odbace bivšeg partnera ne prepoznaju povezanost djeteta s drugim roditeljem. Neki se roditelji ne osjećaju voljenima od svoje djece sve dok njihovo dijete ne pokaže otvorenu naklonost prema njima, kao time i da ne mari za drugog roditelja. Svako odmicanje od drugog roditelja ili pokazivanje negativnih osjećaja prema drugom roditelja njima je trijumf. Na taj način dijete dobiva implicitnu dozvolu za odbacivanje ili loše ponašanje prema drugom roditelju. Na takve roditeljske pritiske djeca odgovaraju negativnim ponašanjima prema drugom roditelju koje nadalje produbljuje sukobe.

\section{Teška narcistična ranjivost}

Na najranjivijem kraju kontinuuma su roditelji koji imaju prilično paranoidnih obmana o bivšem partneru. Oni iskreno vjeruju da bi bivši partner mogao ozlijediti njih ili njihovu djecu zbog čega aktivno djeluju neprijateljski, a sebe vide sebe kao spasitelja ili zaštitnika. Skloni su bivšeg partnera prijavljivati za zlostavljanje i 
zanemarivanje djece, voditi sudske bitke... Traže osvetu i to im često postaje glavna opsesija u životu. Ona je snažan »protuotrov« za nepodnošljivo bolne osjećaje odbačenosti i bespomoćnosti. Ne vide ni minimum vlastite odgovornosti za razvod braka. Ljude procjenjuju na način jesu li »za« ili »protiv« njih. U svojim borbama su nemilosrdni i u njih često direktno uključuju djecu kako bi kaznili bivšeg partnera $\mathrm{i}$ ispravili nepravdu koja im je nanesena. Djecu angažiraju kao saveznike, koriste ih kao špijune protiv drugog roditelja, s malo razumijevanja ili brige o utjecaju koji će to imati na njih. Djeca su ili potpuno na njihovoj strani ili su protiv njih uz drugog roditelja. Ova skupina roditelja često brani kontakt s drugim roditeljem kako djeca ne bi dobila priliku razumjeti realnost i izabrati drugog roditelja. Vjeruju da bi ih drugi roditelj »kontaminirao« $i$ »isprao im mozak«, a to je upravo ono što sami rade djeci. Nisu u stanju tolerirati bilo kakve osjećaje svoje djece prema drugom roditelju. U takvoj situaciji postaju sumnjičavi prema djeci jer smatraju da su se »priklonila« drugoj strani. Ono što je značajno obilježje ove skupine roditelja je da, iako se bore na sudu za svoju djecu, njihov fokus nije u tome da budu roditelji. Općenito su vrlo malo uključeni u brigu oko djece i za njih pokazuju vrlo mali interes. Ustrajno će se boriti za nešto više vremena s djetetom, a potom će u viđanju djeteta biti inatljivi i neredoviti.

lako klasifikacija razina narcistične ranjivosti Johnstona i Campbella (1988.) datira još iz 80-ih godina prošlog stoljeća još je i danas vrlo aktualna. Naime, teški oblici narcistične ranjivosti zapravo stoje u podlozi mnogih oblika manipulativnih ponašanja koje u svojoj knjizi »Otrov razvoda« prepoznaje Warshack (2008.), a s kojima se gotovo svakodnevno susreću stručnjaci koji u praksi rade s populacijom roditelja u razvodu i njihove djece.

Johnston i Campbell (1988.) opisujući odnos izrazito narcistično ranjivog roditelja prema djetetu zapravo opisuju mehanizme koji stoje u podlozi jednog od najekstremnijih oblika indoktrinacije djece u stranoj literaturi poznat je kao PAS parental alienation syndrome, odnosno kao »sindrom otuđenja roditelja« o kojem među prvima počinje govoriti Richard Gardner još davne 1987. godine. „Sindrom otuđenja roditelja« (SOR) podrazumijeva ponašanje jednog roditelja koje ima za cilj »okrenuti« dijete od/protiv drugog roditelja, a intenzitet kojim će roditelj pokušati utjecati na dijete zapravo uvelike ovisi o stupnju narcistične ranjivosti tog roditelja. Posljedice koje takvo ponašanje ostavlja detaljnije su opisane u nastavku poglavlja.

Za razumijevanje toga kako narcizam pridonosi borbi za skrbništvo djece važno je razumjeti odnos između narcizma i roditeljstva. Donner (2006.) navodi da narcistična obilježja osobnosti dovode do poteškoća vezanih uz skrbništvo nad djecom jer su roditelji više usmjereni na vlastitu dobrobit, nego na dobrobit njihove djece. Roditelji koji su u fokusu ovog članka čine se slijepima na učinke koje

\section{8 članci}


njihovo ponašanje ima na njihovu djecu i ne mogu razmišljati izvan svojih vlastitih emocionalnih potreba. Narcizam se koristi kao objašnjenje što neki roditelji umanjuju i odbacuju vrijednost drugog roditelja u životu djeteta... smatraju da oni, bolje nego bilo tko drugi, znaju što je za njihovo dijete dobro... ne mogu vidjeti ni kako, niti zašto, trebaju roditeljstvo dijeliti s bivšim partnerom. Roditelji koji su poniženi i posramljeni razvodom mogu pokušati okriviti drugog roditelja za bračne probleme kako bi sa sebe odmaknuli odgovornost za razvod braka. Za takve je pojedince razvod neprihvatljiv u toj mjeri da kod njih izaziva ozbiljnu anksioznost i depresiju.

S obzirom na sposobnost nošenja s osjećajem poniženja vezanim uz odbacivanje u situaciji razvoda braka te ovisno o stupnju povrede, roditelji inzistiraju na preuzimanju skrbništva nad djecom kako bi sačuvali vlastito samopoštovanje i dokazali sami sebi da su »dobri«, odnosno »bolji« roditelji. Roditelji kod kojih su narcistične povrede snažnije traže način da sa sebe skinu bilo kakvu odgovornost za razvod braka dokazujući da je drugi roditelj posve »loš«. Kod roditelja koji su napuštanje u partnerskom odnosu doživjeli kao duboki napad na sebe i razvili paranoidne ideje izdaje, iskorištavanja i urote, motivirani su prvenstveno odmazdom i kažnjavanjem partnera, a skrbništvo traže kako bi se javno opravdali i onog drugog prikazali krivcem za cjelokupnu situaciju.

Ljubav i divljenje roditelja prema djetetu nije uvijek odraz privrženosti. Roditelji koji vole svoju djecu samo zato jer su djeca dio njih, ili zbog toga što ih dijete voli i treba, iskazuju narcistični tip ljubavi. Radi se u stvari o obliku samoljublja. Roditelji koji se upuštaju u dugotrajne bitke za skrbništvo najčešće nemaju kapacitete razmotriti djetetove potrebe, već je njihovo ponašanje usmjereno prema zadovoljenju vlastitih potreba, nerijetko i na uštrb vlastitog djeteta. Dijete je u situaciji da ga se tretira primarno kao produžetak roditelja, a ne kao osobu s vlastitim osjećajima i potrebama koje mogu biti različite od roditeljskih, barem u odnosu na potrebe i osjećaje djeteta o drugom roditelju. To je oblik narcizma koji se smatra patološkim (Donner, 2006.). Patološki narcizam karakterizira egocentrizam u kojem se druge osobe ne sagledava kao pojedince s vlastitim pravima, već kao produženje samih sebe. Djeca roditelja kod kojih je prisutan patološki narcizam imaju zadatak da moraju zadobiti ljubav i odobravanje. Kada djeca ne mogu zadovoljiti takva očekivanja, roditelji reagiraju bijesom, anksioznošću, depresijom, koju su osjećali i kao djeca kada osoba koja je o njima brinula nije mogla zadovoljiti njihove potrebe. Kada roditelji s patološkim oblikom narcizma izgube vezu s djetetom zbog razvoda, posljedice mogu biti doista duboke. Postoji rizik od potpunog raspada ličnosti, pogotovo ako se radi o gubitku nekoga tko je dio njegovog vlastitog samopoimanja, poput djeteta ili bivšeg partnera, koji narcističnog roditelja drži na okupu i kod njega stvara osjećaj vlastitog identiteta. Kako bi odmaknuli od sebe očaj i 
bespomoćnost koju osjećaju, roditelji počinju prakticirati ponašanja kojima je osnovna svrha omnipotentna kontrola nad svijetom. Kada roditelj s takvim oblikom narcizma izgubi objekt ljubavi, on ne samo da tuguje nad izgubljenom ljubavi, već osjeća da nešto što bi mu trebalo biti dostupno to nije. Ne tuguje za osobom koju je izgubio, već za onim što mu je ta osoba osiguravala. Patološki narcistični roditelj koji se upusti u bitku za skrbništvo može završiti u bitci u kojoj u cijelosti želi preuzeti kontrolu nad odgojem djeteta. Kada bivši partner uzme dijete, narcistični roditelj pod prijetnjom kompletnog raspada odgovara na duboko obrambeni način kako bi sačuvao samog sebe. Spreman je potrošiti značajna novčana sredstva na bitku oko pravnih pitanja, primjerice svega nekoliko sati više sa svojim djetetom, što se može činiti nerazumnim. Ipak, to su roditelji koji se ne bore samo za vrijeme koje će provoditi sa svojim roditeljem, već se bore da zadrže vlastiti integritet (Donner, 2006.).

Narcistični roditelji tretiraju svoju djecu kao produžetak samih sebe, očekujući da djeca zadovolje njihove narcistične potrebe. Istovremeno, nisu u stanju zadovoljiti potrebe svoje djece za prihvaćanjem; kritični su i ljuti, kada njihova djeca pokušavaju izraziti svoje osjećaje, volju i vlastitu osobnost, opstruiraju svoju djecu u razvoju vlastitog »selfa« (Cohen, 1998.). Ipak, narcistična posesivnost prema djetetu nužno ne isključuje emocionalno davanje. Miller (1981., prema Cohen, 1998.) napominje da narcistična majka često voli svoje dijete strastveno. Isto se može reći i za narcistične očeve. Mnogi takvi očevi potrošit će mnogo vremena sa svojom djecom i uložiti mnogo energije u poticanju razvoja svoje djece. Međutim, oni se uglavnom neće fokusirati na emocionalni razvoj svoje djece, već na poticanje intelektualnog, umjetničkog ili sportskog razvoja svoje djece, što će potom služiti kao refleksija i dokaz vlastitog uspjeha kao roditelja.

Narcistično povrijeđen roditelj ima teškoće u definiranju međuljudskih granica. Taj roditelj u pravilu izvrće vlastitu percepciju druge osobe. Tako su, u visokokonfliktnim razvodima, vrlo česte optužbe za seksualno, fizičko ili emocionalno nasilje. Povrijeđeni je roditelj sklon povući i neraskidivu granicu oko sebe i djeteta, bez ikakvog kapaciteta da empatizira s drugim roditeljem. To je ozbiljna distorzija jer roditelji zajednički sudjeluju u odgoju i podizanju djeteta. Takav neempatizirajući roditelj svog bivšeg partnera uopće ne vidi kao drugog roditelja zajedničkog djeteta, već kao običnog stranca. Takve oštre, krute granice, dopuštaju povrijeđenom roditelju da tretira drugog na nevjerojatno okrutan način, bez imalo krivnje. Narcistično povrijeđeni roditelji s manjkom empatije oslobađaju se osjećaja povrede pretjeranim identificiranjem s djetetom. Klinički simptomi takve osobnosti prikazuju roditelja koji se prema drugom roditelju odnosi u trećem licu ili nekom s formalnom titulom kao što je npr. »gospođa«ili »gospodin«.

U razvodu problemi sa samopoštovanjem narcistično povrijeđenih pojedinaca proizlaze iz (1) njihove nesposobnosti da toleriraju unutarnji konflikt ili (2) am-

\section{0 članci}


bivalencije prema samima sebi ili prema drugima u njihovima životima. Ambivalencija je ljudski univerzalan osjećaj. Nitko nije savršen, pa čak niti oni koje najviše volimo. Ako se manjkavosti ili slabosti vide kao »loše«, tada je narcistično ranjiva osoba ugrožena mogućnošću gubitka iluzije da je gotovo savršena. Takav roditelj od djeteta očekuje da bude savršeno i jedino ga tako vidi jer ponašanje djeteta vidi kao refleksiju svojih vlastitih roditeljskih sposobnosti. Pojavljuju se i projekcije jer se manjkavosti i pogreške djece moraju pripisati nekom drugom - »njezina je majka odgovorna što moja kći postiže tako loše rezultate u školi, jer nikada ne radi s njom" ili »on ne brine dobro o djetetu«. Uz to, ako se u drugom roditelju pronađe krivac za djetetove probleme, tada postoji dobro opravdanje da se kontrolira njegov pristup djeci.

Kopetski (1991., prema Barris i sur., 2001.) navodi neke korisne smjernice za prepoznavanje narcistično povrijeđenih pojedinaca koji povećavaju rizik nastanka konflikta u razvodu. Prvo, jednog roditelja se vidi kao ozbiljnu potencijalnu prijetnju dobrobiti djeteta. Postoje nerealni i neutemeljeni strahovi da jedan roditelj nema sposobnost zbrinjavati dijete bez da ga dovede $u$ opasnost. Taj strah je $u$ očima roditelja doista realan i stvarnost prezentira tako uvjerljivo da bez ikakvih problema zavede slušača koji počinje vjerovati da se radi o realnoj opasnosti, a ne običnom strahu. Drugo, povrijeđeni roditelj prezentira djetetu svoje iskrivljene negativne percepcije o drugom roditelju te na taj način zapravo vodi negativnu kampanju »trovanja« dječjeg uma i njegovog okretanja protiv drugog roditelja. Treće, povrijeđeni roditelj govori svojem djetetu i ponaša se prema njemu kao prema svojem vršnjaku. Četvrto, povrijeđeni roditelj otvoreno izražava želju da ograniči kontakte djeteta s drugim roditeljem ili da ih potpuno spriječi. Takve izjave obično se opravdavaju time da postoji dobar razlog za isključivanje roditelja iz života djeteta pri čemu se nabrajaju ozbiljni "zločini« drugog roditelja. I na kraju, peto, povrijeđeni roditelj traži uzdržavanje za dijete ili neki drugi oblik nadoknade za nanesenu mu nepravdu. Uobičajeni primjer je roditelj koji će reći da drugi roditelj koji ne plaća uzdržavanje ne bi trebao imati pravo na viđanje jer je dijete »vlasništvo« roditelja koji brine o njemu.

Obnova samopoštovanja i rekonstrukcija uloge roditelja glavne su zadaće koje roditelj s kojim dijete ne živi mora provesti i završiti. Za narcistične osobnosti, čiji je »self « vrlo ugrožen u procesu razvoda, ta zadaća može biti posebno naporna. Ona podrazumijeva, između ostalog, proživljavanje snažnih osjećaja ljubomore, ljutnje, bespomoćnosti, krivnje i gubitka koje su sastavni dijelovi procesa razvoda i pomirenje s brojnim ograničenjima stvarnosti, prije svega ograničenim daljnjim pristupom svojoj djeci. Za narcistične osobnosti, ipak, primarni je cilj popraviti štetu koju razvod ostavlja na sliku vlastitog samopoštovanja. To podrazumijeva potrebu da se štiti od svijesti o vlastitoj ulozi u propasti braka i osjećajem tuge svoje djece. 
Posljedice koje narcistično roditeljstvo ostavlja na djecu zapravo možemo povezati s posljedicama koje se povezuju s dugotrajnim visokokonfliktinim razvodima. Naime, narcistična ranjivost pojedinca sasvim sigurno je jedan od čimbenika koji pridonose riziku od sukoba tijekom razvoda braka i kasnije ga podržavaju. Poznato je da sukob između supružnika »nagriza« sposobnost roditelja da suradnički sudjeluju u skrbi i odgoju djece. Zbog podijeljenog roditeljskog autoriteta i nedostatka poštovanja roditeljstvo postaje problematičnije - odgoj je uz više prisile, očekivanja su nedosljednija, što je prediktivno za negativniji i distanciraniji odnos na relaciji roditelj-dijete, i povećava rizik od emocionalnih i bihevioralnih problema kod djece. U području utjecaja narcističnog roditeljstva na razvoj djece nedostaje empirijskih istraživanja. Međutim, ponašanja narcističnog roditelja u odnosu na dijete mogu se sagledavati u terminima emocionalnog zlostavljanja djeteta, a to je područje istraživanja bogatije podacima. Arrubarrena i sur. (2013.) smatraju da izloženost djece takvom emocionalnom zlostavljanju ne povećava rizik samo od emocionalnih i bihevioralnih problema u djece, već uključuje i socijalne, kognitivne, pa čak i fizičke probleme. Otuđenje djece od jednog roditelja, opisano u razini teške narcistične ranjivosti roditelja, prema Johnstonu i Campbellu (1988.), može se povezati s rezultatima istraživanja koje su proveli Johnston, Walters i Olesen (2005., prema Bilić, Buljan-Flander i Hrpka, 2012.), koje je pokazalo da djeca koja se otuđuju od jednog roditelja općenito iskazuju više problema u ponašanju u usporedbi s djecom koja se ne otuđuju od roditelja te iskazuju više eksternaliziranih, kao i internaliziranih ponašanja - depresivnija su, povučena, imaju somatske smetnje, agresivnija su u ponašanju.

\section{PRAKTIČNE IMPLIKACIJE}

Zaključno možemo reći da je narcistična ranjivost jedan od prediktora visokokonfliktnog razvoda braka i post razvodne situacije (Baris i sur., 2001.). Navodi ili optužbe jednog roditelja o drugom, dobrom stručnjaku mogu biti važan signal i usmjeravati njegove reakcije u daljnjem radu.

U pružanju intervencija narcistično ranjivim pojedincima važno je znati da, iako nesuglasice s drugima proizlaze iz njihovog ranjivog samopoštovanja, dodatno su potaknute interakcijama s drugima. Uloga drugih ima važan značaj u tome hoće li se nesuglasice ili konflikt intenzivirati i prolongirati.

Polazna točka intervencije narcistično ranjivim pojedincima je pomoći im da oporave svoje ranjeno samopoštovanje i preveniranje daljnjih udaraca na njihov osjećaj vlastite vrijednosti i vlastitog integriteta, smanjujući time njihovu potrebu za priznavanjem ispravnosti (Johnston i Campbell, 1988.). U radu s narcistično ranjivim roditeljima važno je zauzimanje neutralnog, uvažavajućeg i neosuđujućeg

\section{2 članci}


stava. Stručnjaci koji rade s tom populacijom roditelja trebaju se usmjeriti na uočavanje realnih kapaciteta roditelja, jasno naglašavajući njihove posebne snage, podsjećajući na ranija postignuća, dajući značaj dobrim namjerama i aktivno se fokusirati na pozitivna ponašanja, dok taktično treba izbjegavati etiketiranje, okrivljavanje i moguće uvredljive usporedbe s drugim, za njih ugrožavajućim pojedincima. Pažljivo i ozbiljno razmatranje roditeljevih optužbi za zlostavljanje također može imati ključnu ulogu u zadobivanju njihovog povjerenja. Jedino u kontekstu poštovanja i priznavanja njihovih navoda stručnjak može doista ozbiljno provjeriti radi li se o mogućim projekcijama (Johnston i Campbell, 1988.). Kako bi roditelje odvratili od potrebe za zadobivanjem odobravanja od strane bivših partnera, kao do tada uobičajenih, ali sada malo vjerojatnih izvora pozitivnih poticaja, potrebno ih je usmjeriti prema traženju novih izvora razumijevanja i odobravanja. Poticanjem na traženje drugih izvora podrške roditeljima se pomaže u širenju socijalne mreže. Podržavajuća skupina posebno je korisna u dobivanju pozitivnih povratnih informacija, razumijevanja i prihvaćanja roditelja koji se u situaciji razvoda braka osjeća bezvrijedno i poniženo. Isto tako, važno je vraćanje starim hobijima i starim interesima, slijeđenju vlastitih talenata, što pridonosi stjecanju zadovoljstva i vraćanju samopoštovanja.

Uz sve do sada navedeno, stručnjaci se trebaju usmjeriti i na pomoć u olakšavanju izvršavanja nekih praktičnih zadataka vezanih uz razvod, kao što je pronalaženje nekog tko će im pomoći u brizi oko djeteta, obavljanju kućanskih poslova, čime se razvija njihov osjećaj sposobnosti i samodostatnosti. Svi ti napori pomažu u smanjivanju narcističnih povreda, time i smanjenju intenziteta konflikta, odvraćanju fokusa s bivšeg partnera i ublažavanju napora za vraćanjem samopoštovanja kroz bitku za skrbništvo nad djetetom. Za stručnjake koji rade sa ovom populacijom roditelja važno je znati da su to roditelji koji uz adekvatnu stručnu pomoć imaju kapacitete razviti izbalansiranu sliku razvoda kao neuspjeha u održavanju odnosa, koji proizlazi iz problema braka, a ne njih samih. Takvo racionalnije objašnjenje tim pojedincima pomaže u smanjenju osjećaja odbačenosti. Konačno, kapaciteti roditelja da realnije vide svoju djecu i njihova želja da sebe vide kao dobre roditelje, znači da se njihova briga za djecu može kanalizirati u svrhu postizanja promjene.

\section{LITERATURA}

1. Američka psihijatrijska udruga (1994). Dijagnostički i statistički priručnikza mentalne poremećaje - DSM IV. Jastrebarsko: Naklada Slap.

2. Američka psihijatrijska udruga (2014). Dijagnostički i statistički priručnik za duševne poremećaje - DSM V. Jastrebarsko: Naklada Slap. 
3. Arruabarrena, I., de Paúl, J., Indias S. \& Ullate, M. (2013). Psychologists and child psychological maltreatment severity assessment. Psicothema, 25 (4), 482-487.

4. Baris, M. A., Coates, C. A., Duvall, B. B., Garrity, C. B., Johnson, E. T. \& LaCrosse, E. R. (2001). Working with high-conflict families of divorce. New Jersey: Book-mart Press, Inc.

5. Bilić, V., Buljan-Flander, G. \& Hrpka, H. (2012). Nasilje nad djecom i među djecom. Jastrebarsko: Naklada Slap.

6. Bilić, V., Gregurek, R., Marčinko, D., Pavelić, D., Rudan, V., Vidović, V. \& Vlastelica, M. (2013). Narcistični poremećaj ličnosti i njegova dijagnostička opravdanost doprinos međunarodnoj raspravi. Zagreb: Medicinska naklada.

7. Cohen, O. (1998). Parental narcissism and the disengagement of the non-custodial father after divorce. Clinical Social Work Journal, 26 (2), 195-215.

8. Cramer, P. (2011). Narcissism through the ages: What happens when narcissists grow older? Journal of Research in Personality, 45 (5), 479-492.

9. Čuržik, D. \& Jakšić, N. (2013). Patološki narcizam i narcistični poremećaj ličnosti - Pregled suvremenih spoznaja. Klinička psihologija, 5 (1-2), 21-36.

10. Donner, M. B. (2006). Tearing the child apart: The contribution of narcissism, envy, and perverse modes of thought to child custody wars. Psychoanalytic Psychology, 23 (3), 542-553.

11. Gaulier, B., Margerum, J., Price, J. A. \& Windell, J. (2007). Defusing the high-conflict divorce. New Jersey: Impact Publishers.

12. Johnston, J. R. (1994). High-conflict divorce. Children and divorce, 4 (1), 165-182.

13. Johnston, J. R. \& Campbell, L. E. G. (1988). Impasses of divorce: The dynamics and resolution of family conflict. New York: Free Press.

14. Levy, K. N. (2012). Subtypes, dimensions, levels and mental states in narcissism and narcissistic personality disorder. Journal of Clinical Psychology, 68 (8), 886-897.

15. Malcore, S. A., Windell, J., Seyuin, M. \& Hill, E. (2010). Predictors of continued conflict after divorce or separation: Evidence from a high-conflict group treatment program. Journal of Divorce \& Remarriage, 51 (1), 50-64.

16. Miller, J. D., Gentile, B., Wilson, L. \& Campbell, W. K. (2013). Grandiose and vulnerable narcissism and the DSM-5 pathological personality trait model. Journal of Personality Assessment, 95 (3), 284-290.

17. Morey, L. C. \& Stagner, B. H. (2012). Narcissistic pathology as core personality dysfunction: Comparing the DSM-IV and the DSM-V proposal for narcissistic petronality disorder. Journal of Clinical Psychology, 68 (8), 908-921.

18. Raskin, R., Novacek J. \& Hogan, R. (1991). Narcissistic self-esteem management. Journal of Personality and Social Psychology, 60 (6), 911-918. 
19. Roberts, B. W., Kuncel, N. R., Shiner, R., Caspi, A. \& Goldberg, L. R. (2007). The power of personality the comparative validity of personality traits, socioeconomic status, and cognitive ability for predicting important life outcomes. Perspectives on Psychological Science, 2 (4), 313-345.

20. Ronningstam, E. (2011). Narcissistic personality disorder in DSM V-In support of retaining a significant diagnosis. Journal of Personality Disorders, 25 (2), 248259.

21. Warshak, R. A. (2008). Otrov razvoda: Zaštita veze između roditelja i djeteta od osvetoljubivog bivšeg partnera. Zagreb: Algoritam. 
Ljetopis socijalnog rada 2017., 24 (1), 147-166.

\author{
Maja Ernečić \\ Sonja Patrčević \\ Social Welfare Center Koprivnica
}

\title{
NARCISSISTIC VULNERABILITY AND DIVORCE
}

\begin{abstract}
Personality traits define the characteristic and consistent behaviour of individuals, as well as how they react in stressful situations. It is widely accepted that divorce is one of the most stressful events in the life of an individual. The ability of an individual to adapt depends, among other things, on the presence of narcissistic personality traits. Narcissistic vulnerability is a defence mechanism that is activated in situations of intense stress caused by divorce. Even though it is not synonymous to the clinical diagnosis of narcissistic personality disorder, depending on how much self-esteem an individual has lost and the difficulties experienced during recovery, it can develop into pathological narcissism. Narcissistic vulnerability defines the way in which an individual will react to the loss of self-esteem and to what extent it will be threatening for that individual. Over time, most people will solve self-esteem issues and recover. Unlike the majority, having experienced a setback, individuals that are narcissistically more vulnerable will have difficulties recovering and preserving their self-esteem. Self-esteem issues can last for a long time with the same intensity, and the person can develop a narcissistic personality disorder. High-conflict divorce is increasingly becoming the focus of interest of experts, as well as the general public. A number of studies deal with the psychological impacts of conflicts on children, the manipulative behaviours of parents, and difficulties of raising children after divorce. Parents' personality in these areas is recognized as important, yet its influence is insufficiently explained. This paper is one of the first to discuss psychological processes in a narcissistic individual going through divorce that can contribute to an understanding of the actions of former partners and to a better understanding of high-conflict divorces that are recognized today as an extremely important psychosocial problem.
\end{abstract}

Key words: narcissistic vulnerability, divorce, reaction to stress, loss of self-esteem, narcissistic personality disorder.

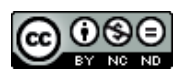

Međunarodna licenca / International License:

Creative Commons Attribution-NonCommercial-NoDerivatives 4.0.

\section{6 Članci}

